УДК 634.836:631.542

Ткаченко О. Б., доктор технічних наук,

Одеська національна академія харчових технологій

Пашковський О. І., здобувач вищої освіти ступеня доктора філософії,

(науковий керівник - доктор технічних наук О. Б. Ткаченко)

Кована О. О., молодший науковий співробітник,

ННЦ «ІВіВ ім. В. Є. Таїрова»

Юрченко С. М.

Київська незалежна судово-експертна установа

\title{
ВПЛИВ СИСТЕМИ ФОРМУВАННЯ КУЩІВ НА СКЛАД МОНОТЕРПЕНІВ ВИНОГРАДУ
}

\section{Рецензент -доктор сільськогосподарських наук Н. А. Мулюкіна}

Мета статmі - дослідити залежність накопичення монотерпенів у ягодах винограду сортів Ароматний та Загрей від вибору системи формування кущів.

Методика дослідження. Схема експерименту включала 4 системи штамбових кордонних формувань, шео відрізнялися за висотою штамба (40, 80, 120, 160 см) та способом ведення однорічного приросту (вертикальне чи вільне). Температуру грон у період дозрівання винограду вимірювали за допомогою безконтактного пірометра. Конщентрацію монотерпенів у винограді визначали методами парової дистилячії та газової хроматографії.

Результати дослідження. При вивченні температурного режиму грон у період дозрівання винограду встановлено, що найвищим значенням показника протягом дня характеризувалися грона низькоштамбових, а найнижчим - високоштамбових кущів.

Визначено доиільність високоштамбових формувань кущзів сорту Ароматний для реалізації ароматичного потенціалу винограду. Застосування такого агротехнічного прийому дозволило отримати сировину з найвищою концентрацією вільної та зв 'язаної фракиії монотерпенів. Як основний компонент в обох фракціях було ідентифіковано ліналоол. Так само для сорту Загрей при формуванні кущів на низьких штамбах зафіксовано найвище накопичення зв'язаної фракції монотерпенів. У розрізі окремих компонентів у такій фракиії превалювали гераніол, ліналоол та бета-циитронелол.

Методами корелячійного та регресійного аналізу виявлено зв'язок між загальним накопиченням зв'язаної фракції монотерпенів і окремих ї̈ компонентів, ліналоолу (сорт Ароматний) та бета-иитронелолу (сорт Загрей), та температурним режимом грон у період дозрівання винограду.

Елементи наукової новизни. Вперше в Украӥні вивчено вплив систем формування кущів на склад монотерпенів винограду. Встановлено доцільність диференційованого в розрізі сортів вибору агротехніки для реалізації їх ароматичного потенціалу.

Практична значущість. Одержані результати можуть застосовуватися у промисловому виноградарстві при створенні нових насаджень сортів Ароматний та Загрей з метою отримання високоякісної сировини для виноробства.

Ключові слова: система формування, Ароматний, Загрей, монотерпени, температура грона, вільна фракиія, зв'язана фракиія.

Ткаченко Оксана Борисівна - доктор технічних наук, доцент кафедри технології вина і енології, Одеська національна академія харчових технологій, вул. Канатна, 112, м. Одеса, 65039, Україна, e-mail: obtkachenko@gmail.com, ORCID ID: 0000-0002-6612-6568.

Пашковський Олександр Ігорович - здобувач вищої освіти ступеня доктора філософії відділу виноробства, Національний науковий центр «Інститут виноградарства i виноробства ім. В. Є. Таїрова», вул. 40 років Перемоги, 27, смт. Таїрове, Одеська область, 65496, Україна, е-таil: aipashkovskiy@gmail.com, ORCID ID: 0000-0003-1882-7199.

Кована Олена Олегівна - молодший науковий співробітник відділу виноробства, Національний науковий центр «Інститут виноградарства і виноробства ім. В. С. Таїрова», вул. 40 років Перемоги, 27, смт. Таїрове, Одеська область, 65496, Україна, e-mail: boichuk.lena@gmail.com, ORCID ID: 00000002-0832-7732. 
Юрченко Євген Миколайович - експерт, Товариство з обмеженою відповідальністю «Київська незалежна судово-експертна установа», вул. Січових стрільців, 21, м. Київ, 04053, Україна, е-таil: sunnik14@yandex.ua.

Постановка проблеми. Забезпечення високого рівня освітленості грон під час дозрівання винограду $є$ одним із основоположних принципів агротехніки. Узагальнення результатів іноземних досліджень дозволяє стверджувати, що виноградні грона, експоновані до сонячного світла, відрізняються підвищеною якістю i, зокрема, рівнем накопичення ароматичних речовин.

Вплив світла на хімічний склад винограду залежить від температури грона, величина якої визначається інтенсивністю фотосинтетично активної радіації в зоні плодоношення. Ферментні системи, що беруть участь в утворенні метаболітів винограду, $\epsilon$ термочутливими та активними у визначених діапазонах температур.

Системи формування кущів представляють собою інструмент управління мікрокліматом грона, тому їхнє дослідження з урахуванням показників якості винограду є актуальними.

Аналіз останніх досліджень і публікацій. Монотерпени $є$ леткими сполуками, що відповідають за широку гаму квіткових, рослинних та фруктових відтінків аромату білих вин, виготовлених із мускатних та деяких немускатних (Рислінг, Трамінер, Шойребе, Шенен блан, Віоньє тощо) сортів винограду. Загалом у винограді та винах ідентифіковано понад 60 сполук указаного класу, найбільш поширеними 3 яких є ліналоол, гераніол, альфа-терпінеол, бета-цитронелол, нерол, лімонен та мірцен $[10,17]$. Останні дослідження свідчать, що представники монотерпенів, 1,4- та 1,8-цінеол також можуть обумовлювати відтінки евкаліпту в ароматі червоних вин Каберне Совіньон, вироблених у Австралії [19].

Монотерпени накопичуються у цитоплазмі клітин шкірочки і м'якоті ягід протягом періоду дозрівання. Вони існують у вільній формі і як глікозиди глюкози, арабінози, рамнози та апіози [3]. Утворення вільної фракції сполук із попередника - гераніл дифосфату регулюється специфічними терпен синтазами. 3 геному V. vinifera виділено 43 гени VviTPS, які кодують дію вказаних ферментів. Приєднання залишку цукру до аглікону та утворення зв'язаної фракції відбувається за участі $\beta$-D-глюкозилтрансфераз, активність яких кодується чотирма генами VviGTs [15].

Зв'язана фракція не має аромату і становить до 90 \% від загальної концентрації монотерпенів

у винограді. При бродінні сусла відбувається вивільнення сенсорно активних агліконів шляхом гідролізу глікозидів ферментами дріжджів [15]. Тому концентрація глікозидів монотерпенів більшою мірою відображає ароматичний потенціал винограду.

Вплив агротехнічних прийомів на накопичення монотерпенів є важливим питанням формування якості винограду. У цьому аспекті рівень освітленості грон вважають ймовірним детермінантом загальної концентрації сполук [7-9, $13,16]$. Сонячна радіація $\mathrm{i}$, що важливіше, пов'язане з нею нагрівання тканин ягід, впливають на швидкість протікання низки метаболічних процесів, зокрема і синтезу монотерпенів. Поліпшення світлового і теплового середовища ягід за рахунок систем формування кущів $[5,11]$, дефоліації зони плодоношення $[4,6,8,9$ 12-14, $18]$, чеканки пагонів $[9,12,14]$, пасинкування $[9,12]$, видалення частини урожаю [12] підвищує концентрацію сполук. Проте в умовах жаркого клімату надмірне підвищення температури грона призводить до блокування синтезу монотерпенів, спричиняє їх біотрансформацію чи випаровування з поверхні ягоди [7].

Перспективні технічні сорти Загрей та Ароматний селекції ННЦ «IBiB ім. В. Є. Таїрова» дозволяють виготовляти сухі білі вина з оригінальним сенсорним профілем. Встановлено, що в ароматичному комплексі цих вин переважною групою компонентів $є$ саме монотерпени [2]. Однак, дослідження впливу прийомів агротехніки на комплекс монотерпенів цих сортів винограду не виконувалося.

Метою роботи було дослідити залежність накопичення монотерпенів у ягодах винограду сортів Ароматний та Загрей від вибору системи формування кущів.

Для досягнення мети були поставлені такі завдання:

- вивчити температурний режим грон у період дозрівання винограду;

- дослідити склад монотерпенів винограду;

- встановити залежність накопичення монотерпенів від умов мікроклімату грона. 
СІЛЬСЬКЕ ГОСПОДАРСТВО. РОСЛИННИЦТВО

\begin{tabular}{|c|c|c|}
\multicolumn{2}{c}{} & \multicolumn{2}{c|}{ 1. Схема досліду } \\
\hline \multirow{2}{*}{ Варіант досліду } & \multicolumn{2}{|c|}{ Характеристики системи формування } \\
\cline { 2 - 3 } & $\begin{array}{c}\text { Висота } \\
\text { штамбу }\end{array}$ & Спосіб ведення однорічного приросту \\
\hline IК (контроль) & 80 & Двобічний горизонтальний кордон/вертикальне \\
\hline II & 40 & Двобічний горизонтальний кордон/вертикальне \\
\hline III & 120 & Двобічний горизонтальний кордон/вільне \\
\hline IV & 160 & Однобічний горизонтальний кордон/вільне \\
\hline
\end{tabular}

Джерело: власні дослідження.

Матеріали і методи досліджень. Об'єктом досліджень були кущі і виноград білих сортів технічного напряму Ароматний і Загрей.

Дослідження проводили у 2016-2018 рр. на ділянках відділу виноградарства ННЦ «IBiB ім. В. Є. Таїрова», розташованих у смт. Таїрове Овідіопольського району Одеської обл., 46 ${ }^{\circ} 21^{\prime}$ ПнШ, 30 38' СхД.

Експериментальна ділянка - 2013 року посадки. Тип грунтів ділянки - південні чорноземи, без зрошення. Схема посадки кущів - 3x1,5 м (Ароматний) та $3 \times 1,3 \times 1,5$ м (Загрей), орієнтація рядів - північ-південь. Кущі щеплені на підщепу РхР 101-14 Mgt. Комплекс агротехнічних прийомів по догляду за насадженнями був загальноприйнятим для такої зони виноградарства.

Схема польового досліду для двох сортів винограду наведена у табл. 1. Число облікових кущів по кожному з варіантів -15 .

Навантаження кущів вічками здійснювали шляхом обрізки відповідно до сили їх росту. До початку цвітіння, коли чітко позначилися суцвіття, проводили нормування кількості зелених пагонів обломуванням безплідних, «двійників» $\mathrm{i}$ найменш плодоносних.

Протягом періоду дозрівання винограду (липень-серпень) 3 тижневим інтервалом вимірювали температуру грон за допомогою безконтактного пірометра моделі GM 320-EN-01. Для цього на 5 кущах кожного варіанту досліду зі східної та західної сторони крони обирали по 3 рівномірно освітлені та затінені грона. Загальна кількість точок вимірювань -8 .

Терміни збору врожаю встановлювали, зважаючи на динаміку показників масової концентрації цукрів, титруємих кислот, $\mathrm{pH}$. При збиранні за варіантами досліду визначали масову концентрацію вільної та зв'язаної фракції терпенових спиртів [1], а також досліджували їх компонентний склад методом газової хроматографії.

Результати досліджень. У ході проведених досліджень нами встановлено, що формування рослин із різною висотою штамба та типом ведення однорічного приросту по-різному впливає на тепловий режим грон.

У ранковий час (9:00) найвищою температурою $\left(33,5^{\circ} \mathrm{C}\right)$ характеризувалися освітлені грона, розташовані на східній стороні крони низькоштамбових кущів. Це зумовлено розміщенням зони плодоношення у пригрунтовому шарі повітря, що додатково прогрівається за рахунок теплової енергії, відбитої від поверхні грунту. Нижній екстремум $\left(25,0^{\circ} \mathrm{C}\right)$ був зафіксований у затінених гронах високоштамбових $(160 \mathrm{~cm})$ формувань. Істотної різниці за значенням мікрокліматичного параметра між освітленими та затіненими гронами на західній стороні крон кущів не встановлено $\left(24^{\circ} \mathrm{C}\right)$.

У полуденні години (13:00) фіксували істотне поліпшення теплового режиму грон, розташованих на західній стороні крони куща. Найвища температура $\left(31,7^{\circ} \mathrm{C}\right)$ була зафіксована в освітлених гронах низькоштамбових кущів. Найнижчу температуру $\left(27,8^{\circ} \mathrm{C}\right)$ зафіксували в затінених гронах на східній стороні крони високоштамбових (160 см) кущів.

Максимальне напруження теплового режиму як експонованих до сонячного світла, так і затінених грон з обох сторін крони куща відзначали після полудня (16:00). Освітлені грона, розташовані на західній стороні крони низькоштамбових кущів, характеризувалися найвищою температурою $\left(39,5{ }^{\circ} \mathrm{C}\right)$. Нижній екстремум температур $\left(28,6{ }^{\circ} \mathrm{C}\right)$ зафіксований у затінених гронах на східній стороні крони при високоштамбовому (120 см) формуванні кущів.

За результатами проведеної роботи нами встановлено, що формування кущів 3 різною висотою штамба та типом ведення однорічного приросту змінює вміст вільної та зв'язаної фракції монотерпенів у ягодах досліджуваних сортів винограду (рис 1, 3, 5).

Істотні різниці за концентрацією вільної фракції монотерпенів (рис. 1а) були встановлені 
між контрольним та усіма дослідними зразками винограду сорту Ароматний.

Найбільше значення показника фіксували у зразках, отриманих 3 низькоштамбових та високоштамбових (120 см) кущів; це значення перевищувало контрольне в середньому в 2,3 рази. Найменше значення показника характеризувало зразок, отриманий 3 високоштамбових (160 см) кущів, і поступалося контрольному у 2,6 раз.

Істотні різниці за концентрацією зв'заної фракції монотерпенів (рис. 1б) виявлені між контрольним та дослідними зразками, отриманими низькоштамбових та високоштамбових (160 см) формувань. У вказаних зразках фіксували найменше значення показника, яке було нижче контрольного у середньому у 4,2 рази. Найбільше значення показника було характерне для зразка, отриманого з високоштамбових (120 см) кущів.

Аналізуючи компонентний склад монотерпенів сорту Ароматний, необхідно зазначити, що превалюючою сполукою у вільній фракції був ліналоол (рис. 2a). Зразки винограду, отримані 3 високоштамбових (120 см) кущів, відрізнялися найвищим вмістом ліналоолу, альфа-терпінеолу та бета-цитронелолу. Найбільше накопичення неролу було властивим для варіанту досліду 3 низькоштамбовим формуванням кущів.

У зв'язаній фракції монотерпенів сорту Ароматний переважав ліналоол, тоді як гераніолу, альфа-терпінеолу та бетацитронелолу містилося у приблизно рівних співвідношеннях (рис. 2б). Зразки винограду, отримані 3 високоштамбових (120 см) кущів, відрізнялися найвищим вмістом ліналоолу, альфа-терпінеолу та бета-цитронелолу. Істотної різниці за вмістом неролу між контрольним i дослідними зразками не встановлено.

Як свідчать експериментальні дані, наведені на рис. 3а, формування кущів сорту Загрей на високих штамбах (120 і 160 см) при схемі садіння 3x1 м сприяло підвищенню концентрації вільної фракції монотерпенів у відношенні до контролю в середньому на $30 \%$.

у вказаній серії дослідів найбільше накопичення зв’заної фракції монотерпенів (рис. 3б) було характерне для зразка, отриманого 3 низькоштамбових кущів; значення показника перевищувало контрольне на 38 \%. Найменше значення показника характеризувало зразок, отриманий з високоштамбових (120 см) кущів, i поступалося контролю на 27 \%.

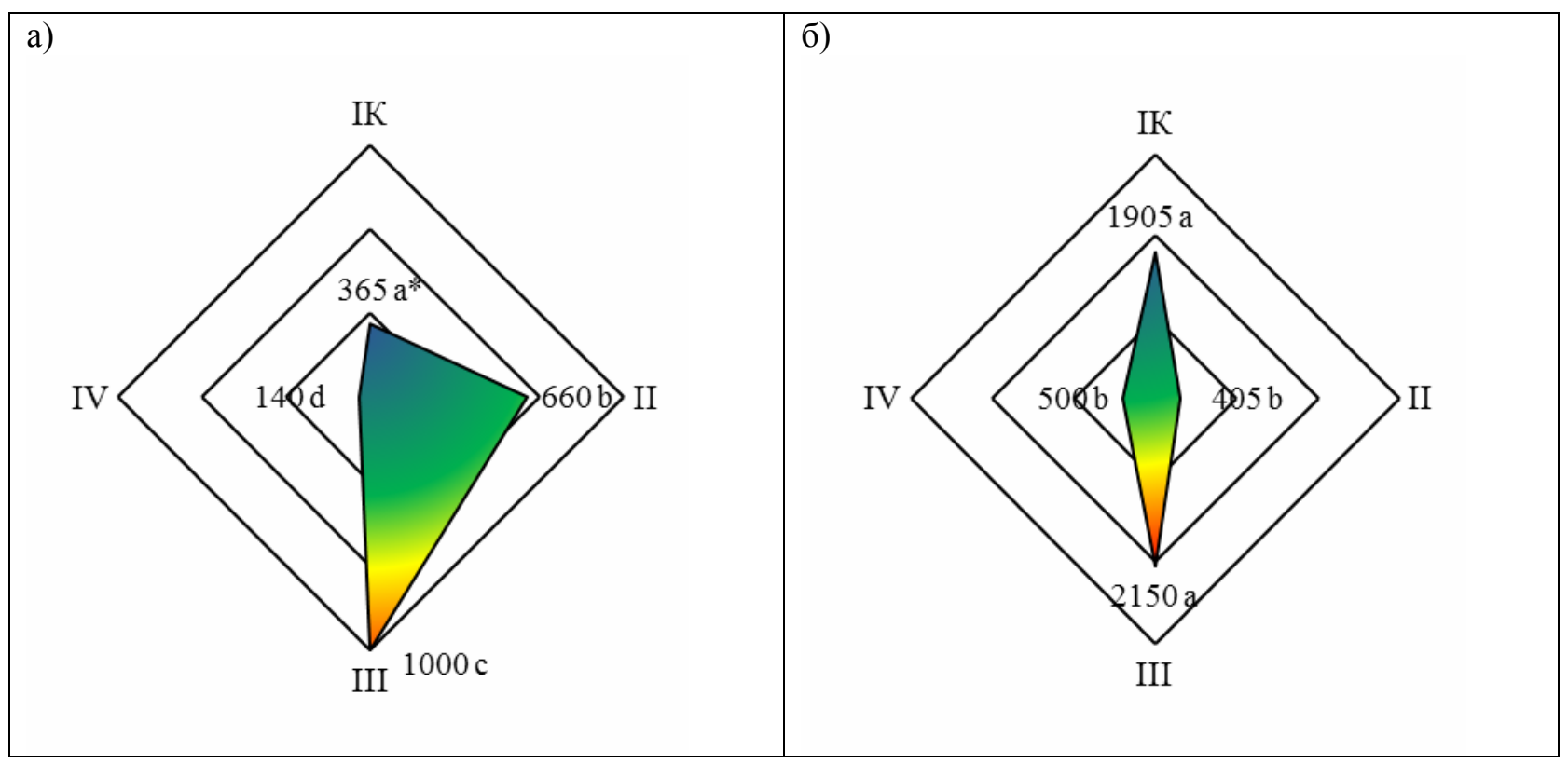

Рис. 1. Вплив системи формування кущів на концентрацію терпенових спиртів у винограді сорту Ароматний, мкг/дм ${ }^{3}$ : а) вільні; б) зв'язані

*Примітка: літери вказують на наявність статистичної різниці між варіантами при множинному парному порівнянні, згідно зі значенням $\mathrm{HIP}_{05}$.

Джерело: власні дослідження. 
a)

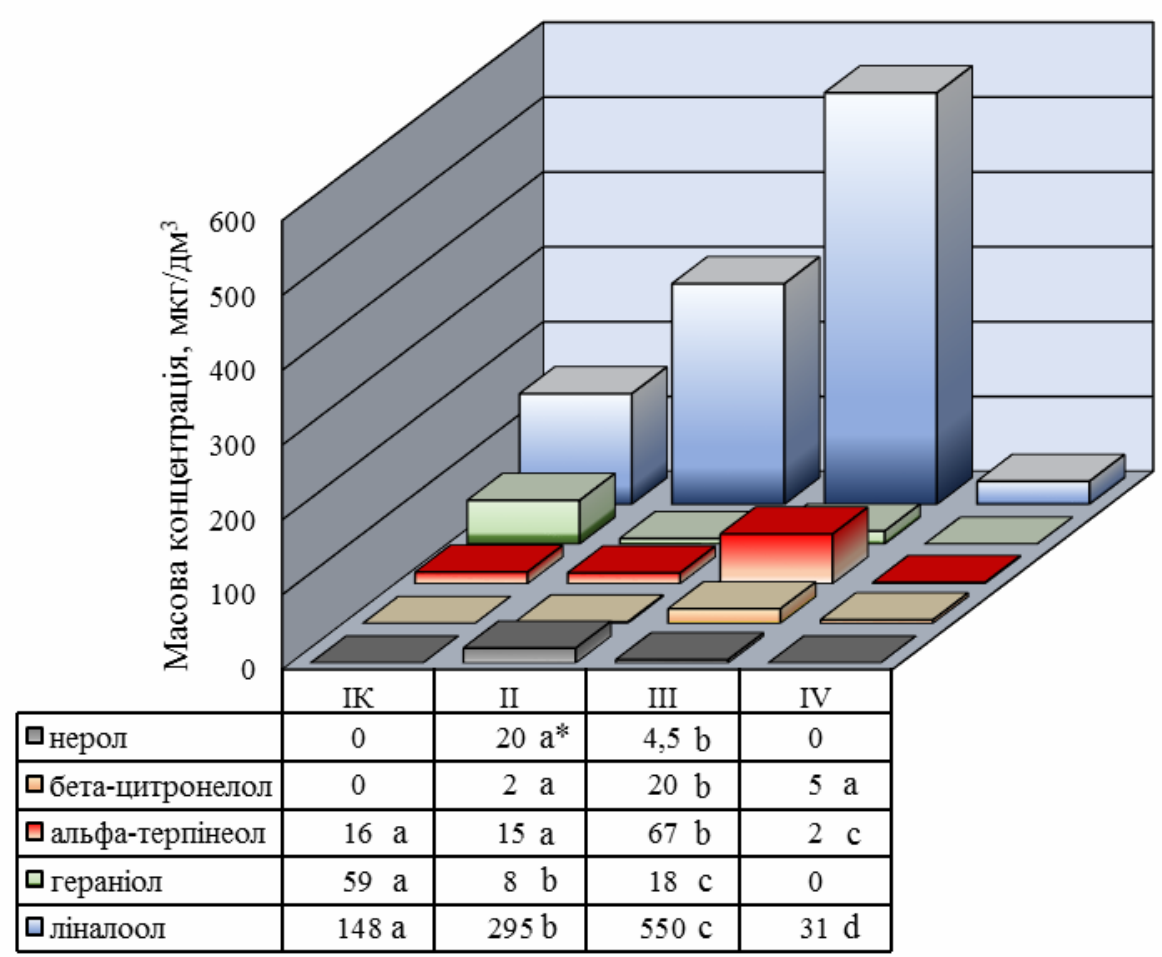

б)

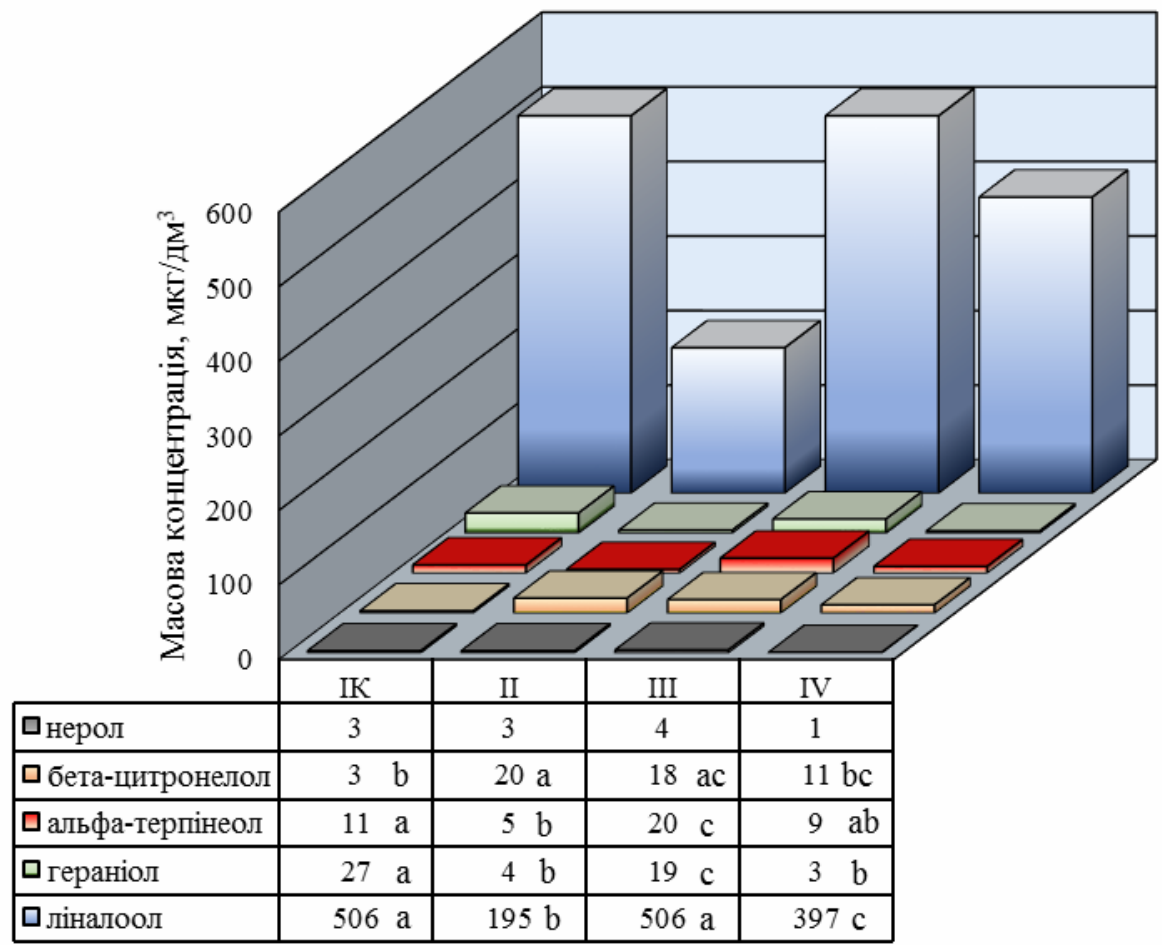

Рис. 2. Вплив системи формування кущів на компонентний склад терпенового комплексу винограду сорту Ароматний, мкг/дм : а) вільні; б) зв'язані

*Примітка: літери вказують на наявність статистичної різниці між варіантами при множинному парному порівнянні, згідно зі значенням НІР 05 .

Джерело: власні дослідження. 
a)

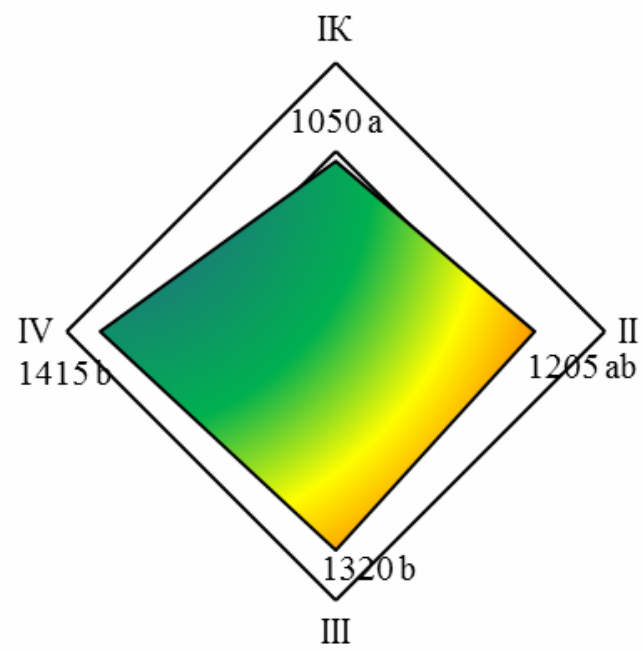

б)

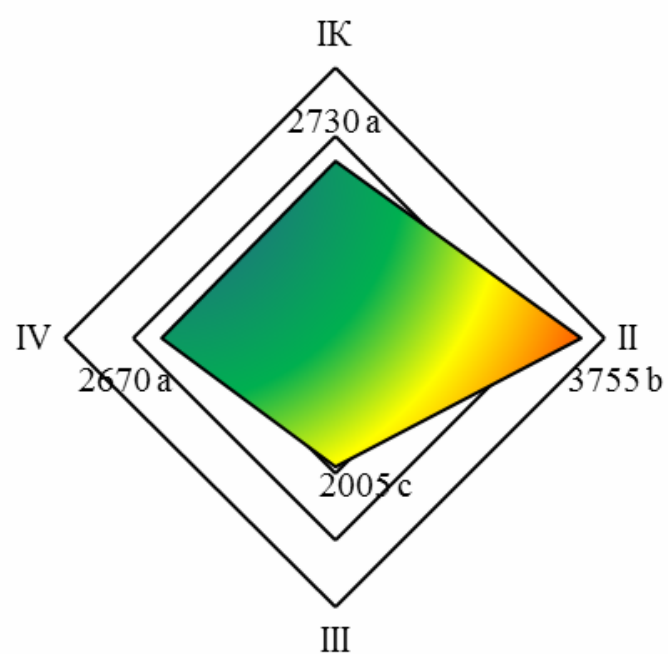

Рис. 3. Вплив системи формування кущів на вміст терпенових спиртів у винограді сорту

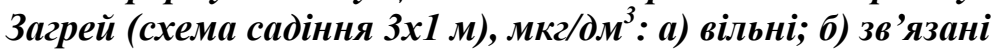

Джерело: власні дослідження.

Аналіз компонентного складу монотерпенів сорту Загрей свідчить, що переважно сполуками у вільній фракції були гераніол, ліналоол та нерол (рис. 4а). Зразки винограду, отримані 3 низькоштамбових кущів, відрізнялись найвищим вмістом гераніолу, альфа-терпінеолу та бетацитронелолу. Найбільше накопичення неролу зафіксовано у варіанті досліду 3 високоштамбовим (160 см) формуванням кущів. Істотної різниці між дослідними зразками за вмістом ліналоолу не встановлено.

У зв’заній фракції монотерпенів сорту Загрей переважали гераніол, нерол ліналоол та бетацитронелол, тоді як альфа-терпінеолу містилося найменше (рис. 4б). Зразки, отримані 3 низькоштамбових кущів, відрізнялись найвищим вмістом неролу, ліналоолу, бета-цитронелолу. Найбільше накопичення гераніолу та альфатерпінеолу відзначено у варіантах досліду, що передбачали високоштамбові (120 см і 160 см) формування кущів.

Згідно 3 даними, наведеними на рис. 5а, формування кущів сорту Загрей на низьких та високих (160 см) штамбах при схемі садіння $3 \times 1,5$ м сприяло підвищенню концентрації вільної фракції монотерпенів порівняно 3 контролем в середньому на $50 \%$.

У вказаній серії дослідів найбільшим накопиченням зв'заної фракції монотерпенів відзначалися зразки, отримані 3 низькоштамбових та високоштамбових $(160 \mathrm{~cm})$ кущів (рис. 5б); значення показника у даних зразках майже вдвічі перевищувало контроль.

Аналізуючи комплекс монотерпенів сорту Загрей за окремими компонентами, встановлено, у вільній фракції переважали гераніол, ліналоол та нерол (рис. 6а). Зразки винограду, отримані 3 низькоштамбових кущів, відрізнялись найвищим вмістом ліналоолу, неролу та альфа-терпінеолу. Найбільше накопичення гераніолу та бетацитронелолу зафіксовано у варіанті досліду, що передбачав високоштамбове (160 см) формування кущів.

У зв'язаній фракції монотерпенів сорту Загрей переважали гераніол, ліналоол та бетацитронелол, тоді як альфа-терпінеолу та неролу містилося найменше (рис. 6б). Зразки, отримані 3 високоштамбових (160 см) кущів, відрізнялись найвищим вмістом гераніолу та ліналоолу. Найбільше накопичення бета-цитронелолу та неролу відзначено у варіанті досліду 3 низькоштамбовим формуванням кущів. Альфатерпінеол містився у рівних кількостях у контрольному та дослідному зразках, отриманих із високоштамбових $(120 \mathrm{~cm})$ кущів. 
a)

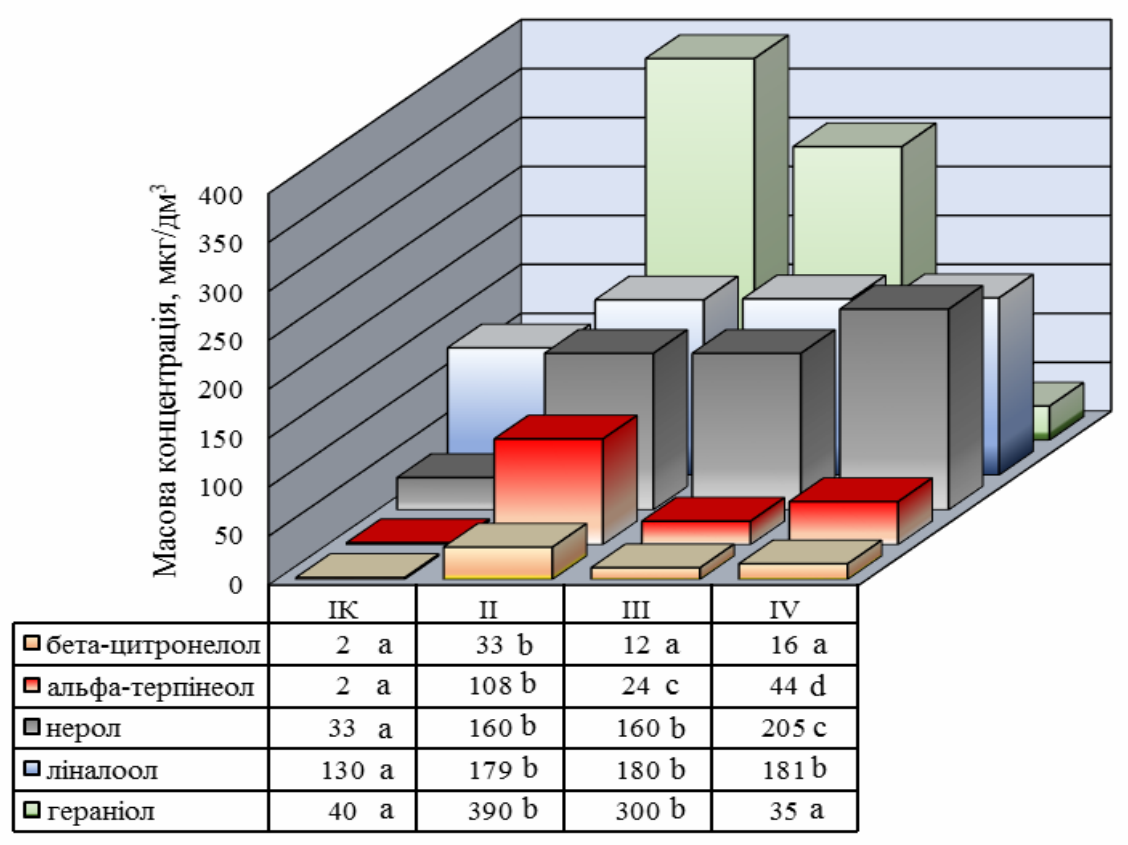

б)

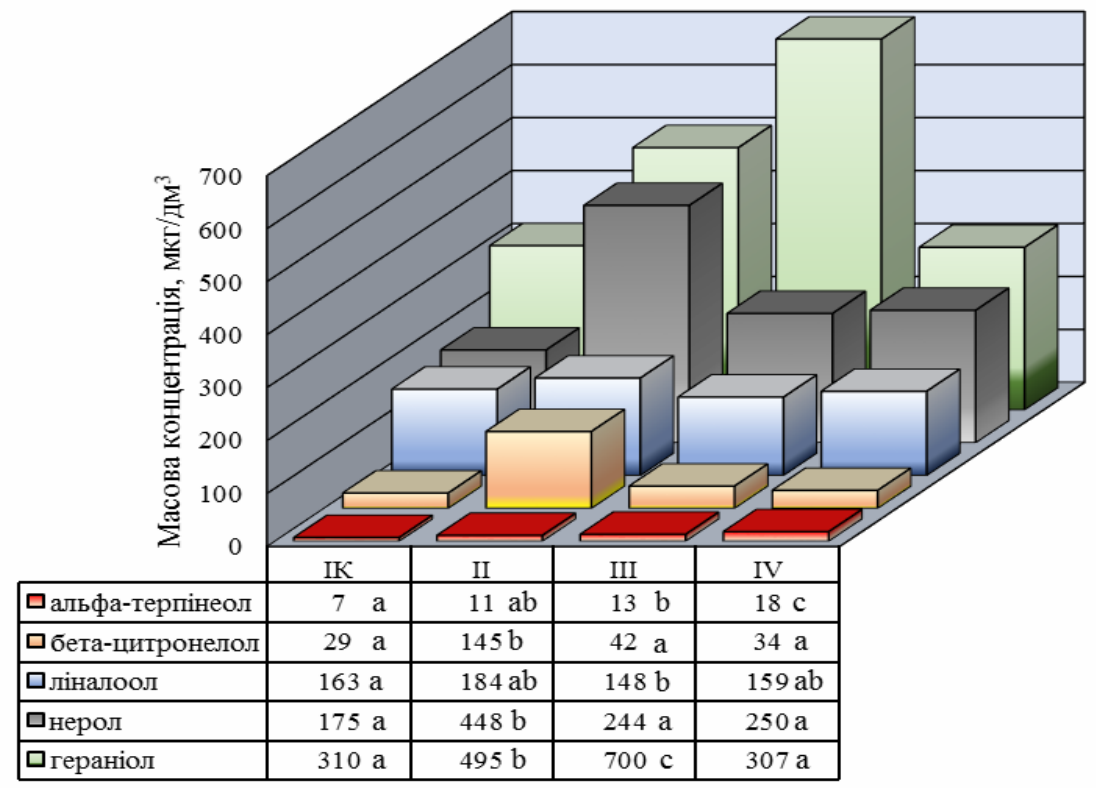

Рис. 4. Вплив системи формування кущів на компонентний склад терпенового комплексу винограду сорту Загрей (схема садіння $3 x 1$ м), мкг/дм ${ }^{3}$ a) вільні; б) зв'язані

Джерело: власні дослідження. 


\section{СІЛЬСЬКЕ ГОСПОДАРСТВО. РОСЛИННИЦТВО}

a)

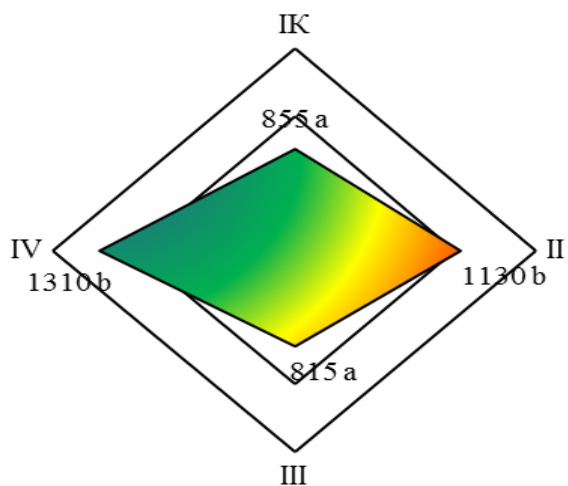

б)

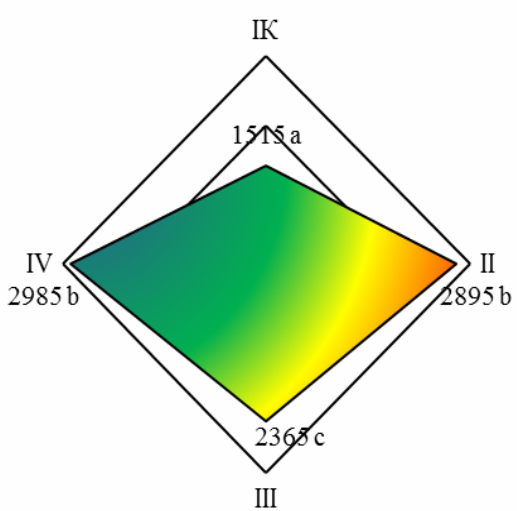

Рис. 5. Вплив системи формування кущів на вміст терпенових спиртів у винограді сорту Загрей (схема садіння $3 \times 1,5$ м), мкг/дм : а) вільні; б) зв'язані

Джерело: власні дослідження.

a)

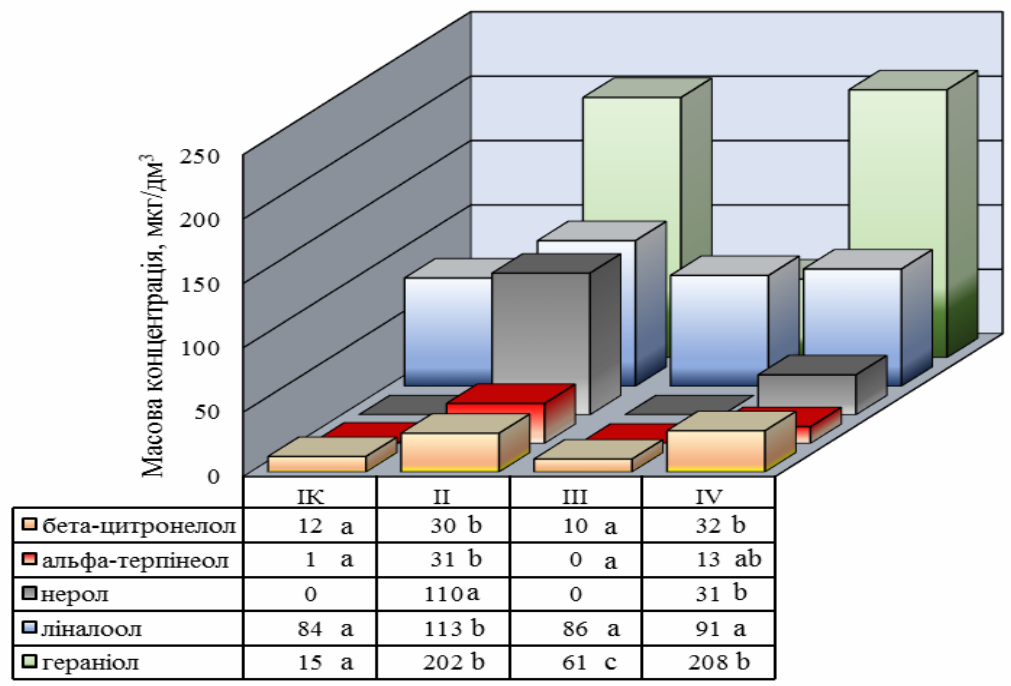

б)

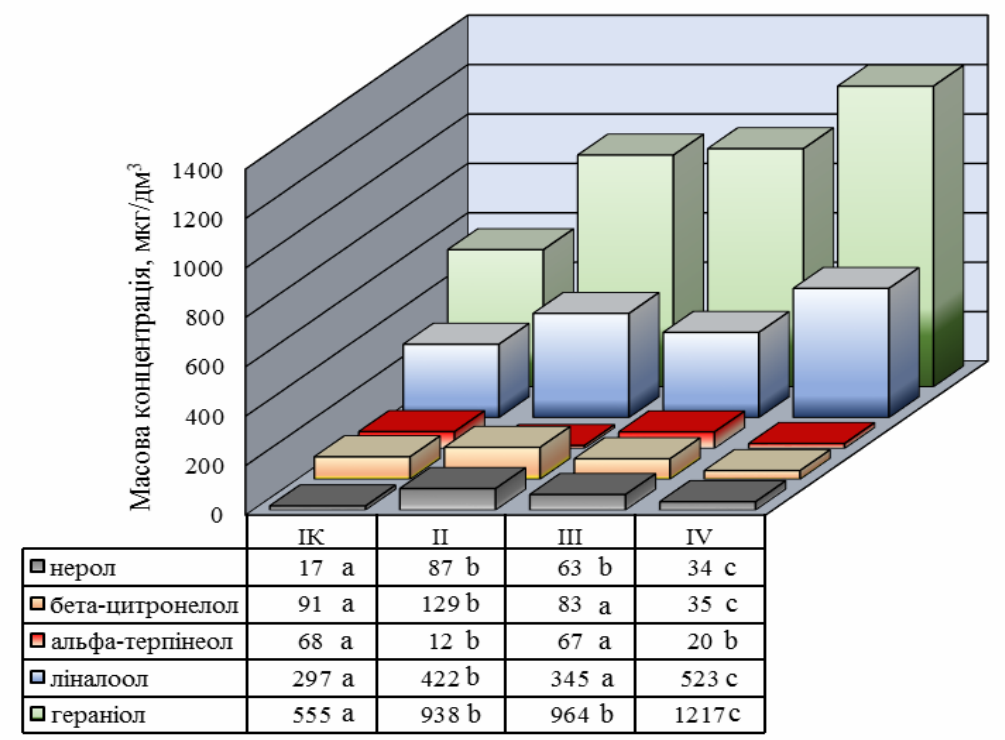

Рис. 6. Вплив системи формування кущів на компонентний склад терпенового комплексу винограду сорту Загрей (схема садіння $3 x 1,5$ м), мкг/дм ${ }^{3}$ : а) вільні; б) зв'язані

Джерело: власні дослідження. 


\section{СІЛЬСЬКЕ ГОСПОДАРСТВО. РОСЛИННИЦТВО}

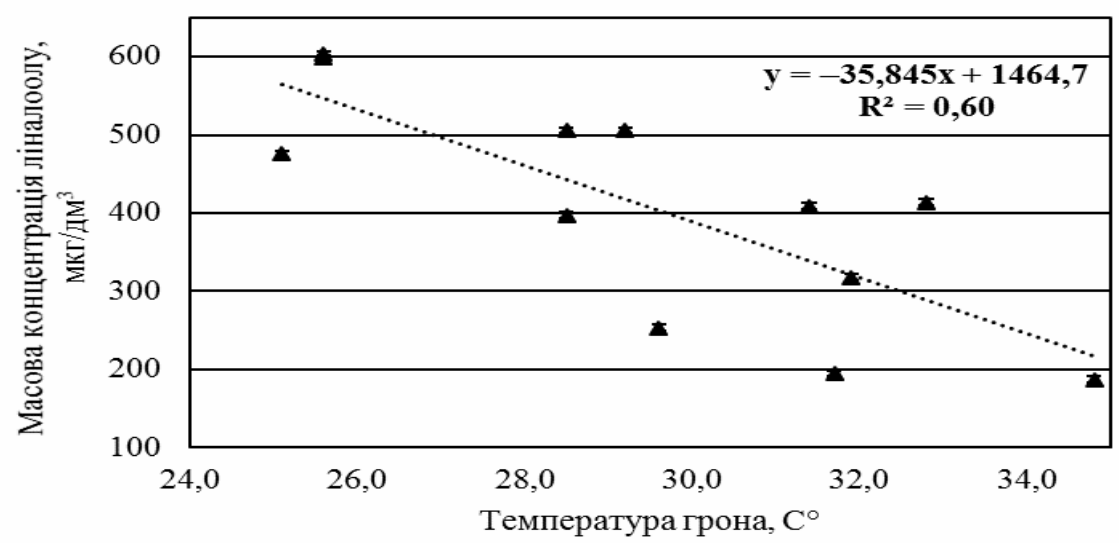

Рис. 7. Залежність накопичення ліналоолу у звязаній фракції монотерпенів сорту Ароматний віठ температури грона

*Примітка: дані за 2016-2018 pр., кожна точка є середнім значенням 3 трьох визначень.

Джерело: власні дослідження.

За результатами кореляційного аналізу встановлено, що накопичення зв'заної фракції монотерпенів у винограді сорту Ароматний пов'язане 3 середньою температурою грона у період дозрівання $(\mathrm{r}=-0,50)$. Значущого зв'зку між накопиченням вільної фракції та мікрокліматичним параметром не виявлено $(\mathrm{r}=-0,24)$.

У розрізі окремих компонентів зв'заної фракції концентрація ліналоолу виявилася найбільш залежною від мікроклімату грона $(\mathrm{r}=-0,78) .3$ літературних джерел відомо, що фермент декарбоксилаза, який бере участь у синтезі сполуки, $€$ чутливим до варіацій освітленності і температури зони плодоношення [7]. У нашій роботі залежність накопичення ліналоолу від температури грона була досить точно $\left(\mathrm{R}^{2}=0,60\right)$ описана рівнянням парної лінійної регресії (рис. 7).

Кореляційний аналіз виявив значущий позитивний зв'язок між накопиченням зв'заної фракції монотерпенів у винограді сорту Загрей та температурою грона $(\mathrm{r}=0,55)$. Подібного звязку між мікрокліматичним параметром та накопиченням вільної фракції монотерпенів не виявлено $(\mathrm{r}=-0,07)$.

У розрізі окремих компонентів зв'заної фракції концентрація бета-цитронелолу виявилася найбільш залежною від мікроклімату грона $(\mathrm{r}=0,78)$. Залежність накопичення бетацитронелолу від температури грона була 3 високим ступенем точності $\left(\mathrm{R}^{2}=0,61\right)$ описана рівнянням лінійної регресії (рис. 8).

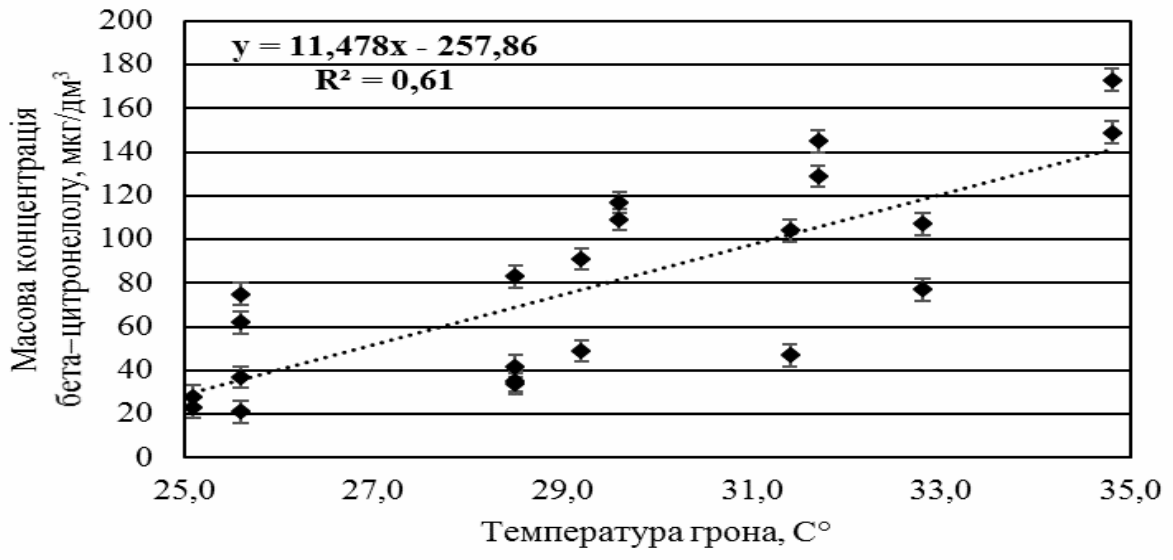

Рис. 8. Залежність накопичення бета-цитронелолу у зв'язаній фракції монотерпенів сорту Загрей від температури грона

Джерело: власні дослідження. 
Висновки. 1. Досліджено вплив системи формування кущів на температурний режим грон у період дозрівання винограду (липень-серпень). Спостереження за денним ходом температур освітлених та затінених грон зі східної та західної сторони крони виявило, що найвищим значенням показника характеризувалися низькоштамбові, а найнижчим - високоштамбові кущі.

2. Досліджено склад монотерпенів винограду залежно від вибору системи формуваня кущів.

При формуванні кущів сорту Ароматний на високих (120 см) штамбах отримали виноград 3 найвищою концентрацією вільної та звязаної фракції монотерпенів. Як основний компонент в обох фракціях було ідентифіковано ліналоол.

При формуванні кущів сорту Загрей на низьких штамбах зафіксовано найбільше накопичення звязаної фракції монотерпенів. Основними компонентами у цій фракції були гераніол, ліна-

\section{БІБЛІОГРАФІЯ}

1. Методы технохимического контроля в виноделии / под ред. В. Г. Гержиковой. Симферополь : Таврида, 2009. $304 \mathrm{c.}$

2. Тринкаль О. В. Удосконалення технології столових білих вин із сортів винограду нової вітчизняної селекції : дис. ... канд. техн. наук : 05.18.05. Київ, 2016. 143 с.

3. Aroma Glycosides in Grapes and Wine / J. Liu, X. Zhu, N. Ullah et al. Journal of Food Science. 2017. Vol. 82, Issue 2. P. 248-259. doi: 10.1111/1750-3841.13598

4. Composition of Sauvignon blanc grapes as affected by pre-veraison canopy manipulation and ripeness level / J. J. Hunter, G. G. Volschenk, J. Marais et al. South African Journal of Enology and Viticulture. 2004. Vol. 25, Issue 1. P. 13-18.

5. Effect of vertical shoot-positioned, Smart-Dyson and Geneva Double-Curtain training systems on Viognier grape and wine composition / B. W. Zoeklein, T. K. Wolf, L. Pelanne, et al. American Journal of Enology and Viticulture. 2008. Vol. 59, Issue 1. P. 11-21.

6. Fruit maturation of four Vitis vinifera cultivars in response to vineyard location and basal leaf removal / A. G. Reynolds, D. A. Wardle, J. W. Hall, et al. American Journal of Enology and Viticulture. 1995. Vol. 46, Issue 4. P. 542-558.

7. Influence of sun exposure on the aromatic composition of Chilean Muscat grape cultivars Moscatel de Alejandria and Moscatel rosada / A. Belancic, E. Agosin, A. Ibacache et al. American лоол та бета-цитронелол.

3. Визначено залежність накопичення монотерпенів від температури грона у період дозрівання винограду.

Встановлено значущий кореляційний звязок між концентрацією зв'заної фракції монотерпенів та температурою грона досліджуваних сортів винограду. У розрізі окремих компонентів найбільшою чутливістю до умов мікроклімату у зоні плодоношення відрізнялися зв'язана форма ліналоолу (Ароматний) та бета-цитронелолу (Загрей).

Отже, в аспекті підвищення якісного потенціалу винограду, вибір системи агротехніки має здійснюватися 3 урахуванням складу ароматичного комплексу та температурного режиму грона в період дозрівання.

Journal of Enology and Viticulture. 1997. Vol. 48, Issue 2. P. 181-186.

8. Macaulay L. E., Morris J. R. Influence of cluster exposure and winemaking processes on monoterpenes and quality of Golden Muscat. Proceedings of 3rd International Cool Climate Viticulture and Oenology Symposium. : American Society for Viticulture and Oenology, 1993. P. 187-190.

9. Marais J., Hunter J. J., Haasbroek P. D. Effect of canopy microclimate, season and region on Sauvignon blanc grape composition and wine quality/ South African Journal of Enology and Viticulture. 1999. Vol. 20, Issue 1. P. 19-30.

10. Marais $J$. Terpenes in the Aroma of Grapes and Wines: A Review. South African Journal of Enology and Viticulture. 1983. Vol. 4, Issue 2. P. 49-58.

11. Reynolds A. G., Wardle D. A., Naylor P. A. Impact of training system, vine spacing and basal leaf removal on Riesling vine performance, berry composition, canopy microclimate and vineyard labor requirements. American Journal of Enology and Viticulture. 1996. Vol. 47, Issue 1. P. 63-76.

12. Reynolds A. G., Wardle D. A. Impact of various canopy manipulation techniques on growth, yield, fruit composition and wine quality of Gewurztraminer. American Journal of Enology and Viticulture. 1989. Vol. 40, Issue 2. P. 121-129.

13. Reynolds A. G., Wardle D. A. Influence of fruit microclimate on monoterpene levels of Gewurztraminer. American Journal of Enology and Viticulture. 1989. Vol. 40, Issue 3. P. 149-154. 


\section{СІЛЬСЬКЕ ГОСПОДАРСТВО. РОСЛИННИЦТВО}

14. Reynolds A. G., Wardle D. A., Dever M. Vine performance, fruit composition and wine sensory attributes of Gewurztraminer in response to vineyard location and canopy manipulation. American Journal of Enology and Viticulture. 1996. Vol. 7, Issue 1. P. 78-92.

15. Schwab W., Wuest M. Understanding the Constitutive and Induced Biosynthesis of Monoand Sesquiterpenes in Grapes (V. vinifera) - A Key to Unlocking the Biochemical Secrets of Unique Grape Aroma Profiles. Journal of Agricultural and Food Chemistry. 2015. Vol. 63. P. 10591-10603. doi: $10.1021 /$ acs.jafc. 5 b04398

16. Smart R. E. Principles of Grapevine Canopy Microclimate Manipulation with Implications for Yield and Quality. A Review. American Journal of Enology and Viticulture. 1985. Vol. 3. P. 230-239.

\section{REFERENCES}

1. Herzhykova, V. H. (Ed.) (2009). Metody tekhnokhymycheskoho kontrolia $v$ vynodelyy [Methods of techno-chemical control in winemaking]. Symferopol: Tavryda [In Russian].

2. Trynkal, O. V. (2016). Udoskonalennia tekhnolohii stolovykh bilykh vyn iz sortiv vynohradu novoi vitchyznianoi selektsii [Improvement of the technology of white table wines from grapes of new domestic selection]. Candidate's thesis. Kyiv [In Ukrainian].

3. Liu, J., Zhu, X., Ullah, N. \& Tao, Y. S. (2017). Aroma Glycosides in Grapes and Wine. Journal of Food Science, 82 (2), pp. 248-259 [In English].

4. Hunter, J. J, Volschenk, G. G., Marais, J. \& Fouche, G. W. (2004). Composition of Sauvignon blanc grapes as affected by pre-veraison canopy manipulation and ripeness level. South African Journal of Enology and Viticulture, 25 (1), pp. 13-18 [In English].

5. Zoeklein, B. W., Wolf, T. K., Pelanne, L. \& Miller, M. K. (2008). Effect of vertical shootpositioned, Smart-Dyson and Geneva Double-Curtain training systems on Viognier grape and wine composition. American Journal of Enology and Viticulture, 59 (1), pp. 11-21 [In English].

6. Reynolds, A. G., Wardle, D. A., Hall, J. W. \& Dever, M. (1995). Fruit maturation of four Vitis vinifera cultivars in response to vineyard location and basal leaf removal. American Journal of Enology and Viticulture, 46 (4), pp. 542-558 [In English].

7. Belancic, A., Agosin, E., Ibacache, A., Bordeu, E., Baumes, R., Razungles, A. \& Bayonove, C. (1997). Influence of sun exposure on the aromatic composition of Chilean Muscat grape cultivars Moscatel de Alejandria and Moscatel rosada. American
17. The Biochemistry of the Grape Berry / by ed. S. Delrot. Sharjah : Bentham Science Publishers, 2012. $290 \mathrm{p}$.

18. Viticultural and oenological implications of leaf removal for New Zealand vineyards / S. Smith, I. C. Codrington, M. Robertson et al. Proceedings of 2nd International Cool Climate Viticulture and Oenology Symposium. Aukland: New Zealand Society for Viticulture and Oenology, 1988. P. 127-133.

19. Wine Aroma Compounds in Grapes: A Critical Review / C. González-Barreiro, R. RialOtero, B. Cancho-Grande et al. Critical Reviews in Food Science and Nutrition. 2015. Vol. 55, Issue 2. P. 202-218. doi: 10.1080/10408398.2011.650336

Journal of Enology and Viticulture, 48 (2), pp. 181-186 [In English].

8. Macaulay, L. E. \& Morris, J. R. (1993). Influence of cluster exposure and winemaking processes on monoterpenes and quality of Golden Muscat. Proceedings of $3 \mathrm{rd}$ International Cool Climate Viticulture and Oenology Symposium. (pp. 187-190). American Society for Viticulture and Oenology [In English].

9. Marais, J., Hunter, J. J. \& Haasbroek, P. D. (1999). Effect of canopy microclimate, season and region on Sauvignon blanc grape composition and wine quality. South African Journal of Enology and Viticulture, 20 (1), pp. 19-30 [In English].

10.Marais, J. (1983). Terpenes in the Aroma of Grapes and Wines: A Review. South African Journal of Enology and Viticulture, 4 (2), pp. 49-58 [In English].

11.Reynolds, A. G., Wardle, D. A. \& Naylor, P. A. (1996). Impact of training system, vine spacing and basal leaf removal on Riesling vine performance, berry composition, canopy microclimate and vineyard labor requirements. American Journal of Enology and Viticulture, 47 (1), pp. 63-76 [In English].

12.Reynolds, A. G. \& Wardle, D. A. (1989). Impact of various canopy manipulation techniques on growth, yield, fruit composition and wine quality of Gewurztraminer. American Journal of Enology and Viticulture, 40 (2), pp. 121-129 [In English].

13.Reynolds, A. G. \& Wardle, D. A. (1989). Influence of fruit microclimate on monoterpene levels of Gewurztraminer. American Journal of Enology and Viticulture, 40 (3), pp. 149-154 [In English].

14.Reynolds, A. G., Wardle, D. A. \& Dever, M. (1996). Vine performance, fruit composition and wine sensory attributes of Gewurztraminer in response to 


\section{СІЛЬСЬКЕ ГОСПОДАРСТВО. РОСЛИННИЦТВО}

vineyard location and canopy manipulation. American Journal of Enology and Viticulture, 7 (1), pp. 78-92 [In English].

15.Schwab, W. \& Wuest, M. (2015). Understanding the Constitutive and Induced Biosynthesis of Monoand Sesquiterpenes in Grapes (V. vinifera) - A Key to Unlocking the Biochemical Secrets of Unique Grape Aroma Profiles. Journal of Agricultural and Food Chemistry, 63, pp. 10591-10603 [In English].

16.Smart, R. E. (1985). Principles of Grapevine Canopy Microclimate Manipulation with Implications for Yield and Quality. A Review. American Journal of Enology and Viticulture, 3, pp. 230-239 [In English].
17. The Biochemistry of the Grape Berry. Delrot, S. (Ed.). Sharjah: Bentham Science Publishers [In English].

18.Smith, S., Codrington, I. C., Robertson, M. \& Smart, S. E. (1988). Viticultural and oenological implications of leaf removal for New Zealand vineyards. Proceedings of 2nd International Cool Climate Viticulture and Oenology Symposium, (pp. 127-133). Aukland: New Zealand Society for Viticulture and Oenology [In English].

19. González-Barreiro, C., Rial-Otero, R., CanchoGrande, B. \& Simal-Gandara, J. (2015). Wine Aroma Compounds in Grapes: A Critical Review. Critical Reviews in Food Science and Nutrition, 55 (2), pp. 202-218 [In English].

\section{Ткаченко О. Б., Пачковський А. И., Кована Е. О., Юрченко Е. Н. Влияние системы формирования кустов на склад монотерпенов винограда}

Цель статьи - исследовать зависимость накопления монотерпенов в ягодах винограда сортов Ароматный и Загрей от выбора системы формирования кустов.

Методика исследования. Схема эксперимента включала 4 системы штамбовых кордонных формирований, которые отличались по высоте штамба (40, 80, 120, 160 см) и способа ведения однолетнего прироста (вертикальное или свободное). Температуру гроздей в период созревания винограда измеряли с помощью бесконтактного пирометра. Концентрацию монотерпенов в винограде определяли методами паровой дистилляции и газовой хроматографии.

Результаты исследования. При изучении температурного режима гроздей в период созревания винограда установлено, что наиболее высоким значением показателя в течение дня характеризовались грозди низкоштамбовых, а самым низким - высокоштамбовых кустов.

Определена иелесообразность высокоштамбовых формирований кустов сорта Ароматный для реализачии ароматического потенциала винограда. Применение данного агротехнического приема позволило получить сырье с наиболее высокой конщентрачией свободной и связанной фракции монотерпенов. В качестве основного компонента в обеих фракииях был идентифицирован линалоол. Подобным образом, для сорта Загрей при формировании кустов на низких штамбах зафиксировано наиболее высокое накопление связанной фракции монотерпенов. В разрезе отдельных компонентов в данной фракции превалировали гераниол, линалоол и бета-цитронелол.

Методами корреляционного и регрессионного анализа выявлена связь между общим накоплением связанной фракиии монотерпенов и отдельных ее компонентов, линалоола (сорт Ароматный) и бетацитронелола (сорт Загрей), и температурным режсиом гроздей в период созревания винограда.

Элементы научной новизны. Впервые в Украине изучено влияние систем формирования кустов на состав монотерпенов винограда. Установлена целесообразность дифференцированного в разрезе сортов выбора агротехники для реализации их ароматического потенциала.

Практическая значимость. Полученные результаты могут применяться в промылиленном виноградарстве при создании новых насаждений сортов Ароматный и Загрей с иелью получения высококачественного сырья для виноделия.

Ключевые слова: система формирования, Ароматный, Загрей, монотерпены, температура грозди, свободная фракиия, связанная фракиия.

Ткаченко Оксана Борисовна - доктор технических наук, доцент кафедры технологии вина и энологии, Одесская национальная академия пищевых технологий, ул. Канатная, 112, г. Одесса, 65039, Украина, e-mail: obtkachenko@gmail.com, ORCID ID: 0000-0002-6612-6568.

Пашковский Александр Игоревич - соискатель высшего образования степени доктора философии отдела виноделия, Национальный научный центр «Институт виноградарства и виноделия им. В. Е. Таирова», ул. 40 лет Победы, 27, пгт. Таирово, Одесская область, 65496, Украина, е-таil: aipashkovskiy@gmail.com, ORCID ID: 0000-0003-1882-7199.

Кована Елена Олеговна - младший научный сотрудник, отдел виноделия, Национальный научный 
центр «Институт виноградарства и виноделия им. В. Е. Таирова», ул. 40 лет Победы, 27, пгт. Таирово, Одесская область, 65496, Украина, e-mail: boichuk.lena@gmail.com, ORCID ID: 0000-0002-0832-7732.

Юрченко Евгений Николаевич - эксперт, Общество с ограниченной ответственностью «Киевское независимое судебно-экспертное учреждение», ул. Сечевых Стрельцов, 21, г. Киев, 04053, Украина, e-mail: sunnik14@yandex.ua.

Tkachenko O. B., Pashkovskyi O. I., Kovana O. O., Yurchenko Ye. M. The impact of bush forming system on monoterpene composition of grapes

The aim of the article is to study the dependence of accumulating monoterpenes in grape berries of Aromatnyi and Zagrey varieties on the choice of bush forming systems.

The methods of research. The scheme of the experiment included 4 systems of stem boundary formations that differed in height $(40,80,120,160 \mathrm{~cm})$ and the method of keeping one-year growth (vertical or non-positioned). The temperature of bunches during grape ripening period was measured, using a contactless pyrometer. The concentration of monoterpenes in grapes was determined by means of steam distillation and gas chromatography.

The results of the study. Studying the temperature regime of bunches during grape ripening period, we established that bunches of low-stemmed bushes were characterized by the highest index value during the day, while the bunches of high-stemmed bushes - by the lowest one.

The expediency of high-stemmed bush formations of Aromatnyi variety for realizing the grape aromatic potential has been determined. The using of this viticulture practice enabled to obtain raw product with the highest concentration of free and bound fraction of monoterpenes. Linalool was identified as the main component in both fractions. Similarly, for Zagrey variety, during bush forming on low stems, the highest accumulation of the bound fraction of monoterpenes was recorded. Geraniol, linalool and beta-citronellol prevailed in separate components of this fraction.

Using the methods of correlation and regression analysis the connection between the total accumulation of monoterpenes' bound fraction and its separate components, linalool (Aromatnyi variety) and beta-citronellol (Zagrey variety) and the temperature of bunches during the ripening period was established.

The elements of scientific novelty. For the first time in Ukraine, the impact of bush forming systems on grape monoterpenes composition has been studied. The expediency of differentiated choosing viticulture practices in the context of varieties for the realization of their aromatic potential has been established.

Practical significance. The results can be used in industrial viticulture when creating new plantations of Aromatnyi and Zagrey varieties in order to obtain high-quality raw product for winemaking.

Key words: system of formation, Aromatnyi, Zagrey, monoterpenes, bunch temperature, free fraction, bound fraction.

Tkachenko Oksana Борисівна - Doctor of Technical Science, Associate Professor, Department of Wine Technology and Oenology, Odessa National Academy of Food Technologies, 112, Kanatna st., Odesa, 65039, Ukraine, e-mail: obtkachenko@gmail.com, ORCID ID: 0000-0002-6612-6568.

Pashkovskyi Oleksandr Ihorovych - post-graduate student, Department of Winemaking, National Scientific Centre "Institute of Viticulture and Winemaking named after V. E. Tairov", 27, 40 Rokiv Peremohy st., township Tairovo, Odesa region, 65496, Ukraine, e-mail: aipashkovskiy@gmail.com, ORCID ID: 0000-0003-1882-7199.

Kovana Olena Olehivna - junior scientist, Department of Winemaking, National Scientific Centre "Institute of Viticulture and Winemaking named after V. E. Tairov", 27, 40 Rokiv Peremohy str., township Tairovo, Odesa region, 65496, Ukraine, e-mail: boichuk.lena@gmail.com, ORCID ID: 0000-0002-0832-7732.

Yurchenko Yevhen Mykolaiovych - expert, LLC "Kyiv Independent Forensic-Expert Examination Institution”, 21, Sichovykh Striltsiv st., 04053, Kyiv, e-mail: sunnik14@yandex.ua.

Стаття надійшла до редакції 01.03.2019 р.

Бібліографічний опис для цитування :

Ткаченко О. Б. Пашковський О. І., Кована О. О., Юрченко С. М. Вплив системи формування кущів на склад монотерпенів винограду. Вісник ПДАА. 2019. № 1. С. 81-93.

DOI 10.31210/visnyk2019.01.10

(C) Ткаченко Оксана Борисівна, Пашковський Олександр Ігорович, Кована Олена Олегівна, Юрченко Свген Миколайович, 2019 